\section{DIGITAL COMMONS \\ @ UNIVERSITY OF SOUTH FLORIDA}

\section{ABO: Interactive Journal for Women in the Arts, 1640-1830}

Volume 5

Issue 1 Volume 5.1 (Spring 2015)

Article 6

2015

\title{
Review of Kerri Andrews, Ann Yearsley and Hannah More, Patronage and Poetry
}

\author{
Catherine Keohane \\ Montclair State University, keohanec@mail.montclair.edu
}

Follow this and additional works at: https://digitalcommons.usf.edu/abo

Part of the Feminist, Gender, and Sexuality Studies Commons, and the Literature in English, British Isles Commons

\section{Recommended Citation}

Keohane, Catherine (2015) "Review of Kerri Andrews, Ann Yearsley and Hannah More, Patronage and Poetry," ABO: Interactive Journal for Women in the Arts, 1640-1830: Vol.5: Iss.1, Article 6.

http://dx.doi.org/10.5038/2157-7129.5.1.5

Available at: https://digitalcommons.usf.edu/abo/vol5/iss1/6

This Reviews is brought to you for free and open access by Digital Commons @ University of South Florida. It has been accepted for inclusion in ABO: Interactive Journal for Women in the Arts, 1640-1830 by an authorized administrator of Digital Commons @ University of South Florida. For more information, please contact digitalcommons@usf.edu. 
Review of Kerri Andrews, Ann Yearsley and Hannah More, Patronage and Poetry

Abstract

Review of Ann Yearsley and Hannah More, Patronage and Poetry by Kerri Andrews.

Keywords

Ann Yearsley, Hannah More, patronage, literary networks, publishing

Creative Commons License

(c) (1) $\odot$

This work is licensed under a Creative Commons Attribution-No Derivative Works 3.0 License. 
Kerri Andrews, Ann Yearsley and Hannah More, Patronage and Poetry. London and Brookfield, VT: Pickering \& Chatto, 2013. x +188pp. Index. ISBN: 978-184893-151-0.

Reviewed by Catherine Keohane Montclair State University

Beginning in the late 1980s, scholars of the long eighteenth century have paid renewed attention to Hannah More's patronage of the laboring-class poet Ann Yearsley and their famous quarrel, while offering increasing, though still relatively limited, attention to Yearsley's writings and her relationships with later patrons. In the introduction to Ann Yearsley and Hannah More, Patronage and Poetry, Kerri Andrews rightly challenges scholars' disproportionate focus on the women's 18-month-long working relationship. In her study, Andrews offers an expanded view of the women and their literary careers. Drawing on archival research, Andrews looks back to More's relationship with the renowned playwright, producer, and actor David Garrick and forward to Yearsley's later literary career as she works to understand the women's engagement in various literary networks. This focus dictates a cultural and historical approach, with limited literary analysis. Potential readers should be aware that, despite her nicely alliterative title, Andrews considers the wider range of genres in which these two women wrote and, more importantly, does not offer any special consideration of poetry as a genre.

Although More and Yearsley's relationship retains a central place in her analysis, Andrews aims to present a "reassessment of our understanding of patronage, friendship and of eighteenth-century and early Romantic literary cultures" (8) in this offering in Pickering \& Chatto's Gender and Genre series. Doing so involves asserting several claims: that More and Yearsley's relationship should be considered a partnership in which each was emotionally invested, that each woman followed the other's career and allowed that interest to shape her own, that we should consider those careers in terms of the larger literary networks in which the women participated, and that Yearsley developed a "hybrid form" of patronage (7). Andrews is especially successful in developing the last two claims and in meeting her goal of opening up areas for further exploration. Literary networks offer an intriguing lens through which to view the women's work and interaction, although there is some murkiness in the term. For example, Andrews asserts that "patronage is also considered a form of 'literary network'," while also arguing that Yearsley attempted to "blend[] elements of patronage with aspects of a literary network" after her break from More (7). This blurred terminology of course reflects the potential overlapping of patronage, friendship, and literary 
relationships during the period and is suggestive of Andrews's argument that patronage involves more than just patron and protégée but a wider network of supporters and friends.

Organized chronologically and topically, the book is divided into six chapters, with a separate introduction and afterword. Chapter one discusses Garrick and More's relationship as one that began as patronage in 1774 and grew into friendship by mid-1776. Following the contemporary model of patronage by offering mentorship more than financial support, Garrick not only helped More revise her plays and get them staged but more importantly gave her access to London's intellectual circles. Patrons gave protégées the "power to gain" or earn a living by their writing, and, for Andrews, Garrick offered this power to More "through his rigorous (and relentless) schooling of her as a dramatic writer" (15). Yet, as she argues, Garrick's patronage "must be considered a failure" (25) because he so completely managed the work involved in staging plays that More was unable to do this for herself later, stalling her career as a playwright. Andrews concludes the chapter with a bold and intriguing claim: "More's experiences as Garrick's protégée, both good and bad, would be crucial in shaping how she behaved as patron to Ann Yearsley in 1784-5; the consequences of More not learning from Garrick's mistakes would be felt for the rest of her career" (25).

As chapter two begins, however, it is clear that this claim is shaky. In tracing the promise and collapse of More and Yearsley's relationship, Andrews asserts a parallel to More and Garrick's in that both patrons invested their protégées' earnings in the same fund. Crucially, however, More retains control over the money, while Garrick does not. Indeed, Garrick's model is most notable for how it differs from More's, suggesting that More never intended to draw on it in her dealings with Yearsley (beyond choosing a familiar fund) and not that she failed to learn from his mistakes. Earlier critics' arguments concerning the class bias inherent in More's treatment of Yearsley retain their force: as Andrews's discussion of More's correspondence shows, More saw Yearsley not as a fellow writer but an object of charity, precluding any friendship of the sort that developed between More and Garrick, and providing a rationale for More not to offer Yearsley the "power to gain" (29).

The chapter offers a more important contribution by reproducing and analyzing a letter Yearsley wrote to More following their quarrel, one previously known only through More's selective quoting and rewriting of it in a letter to Elizabeth Montagu. This archival discovery and Andrews's analysis of it form one of the highlights of the book. As Andrews argues, the letter shows Yearsley drawing on the maternal authority More had elsewhere assigned her as she claims her right to 
access the trust, while More's editing and selective quoting of the letter strives to undercut that authority.

In chapter three, Andrews looks at the broader literary networks of both women between 1785-90, beginning with More's investment in the success of Yearsley's first volume and then discussing some of Yearsley's poems to benefactors.

Arguing that Yearsley valued intellectual help, Andrews connects a point made by earlier scholars (including Yearsley's literary biographer, Mary Waldron) to her own point about what More valued in her relationship with Garrick. Andrews then presents Yearsley's relationships with her later patrons (in particular, Frederick Hervey, the Earl of Bristol; Sarah Shiells; and Eliza Dawson) as illustrating a "hybrid" type of patronage: ". . . Yearsley was able to take the parts of patronage that suited her best - the protection, the companionship and the connections patrons could bring - and reject those that did not suit: the control, the editorial influence and the enforced branding of the patronized poet" (80). Andrews also briefly discusses More's finding comfort in the Bluestocking circle after the collapse of her relationship with Yearsley.

Chapter four takes up the rivalry between the women in the years 1787-91, a period during which More turned to writing the moral and religious texts that would make her reputation. Andrews offers a brief discussion of the two women's abolitionist poems, explaining that More's Slavery, a Poem (1788) developed out of contacts made earlier through Garrick, while Yearsley's Poem on the Inhumanity of the Slave Trade (also 1788) was the poet's first publication printed without a list of subscribers. In addition, Andrews recounts Yearsley's and her patrons' (unsuccessful) efforts to convince Richard Brinsley Sheridan to produce her play Earl Goodwin at the Drury Lane Theatre (where More's plays had been produced in the 1770s), while also reporting on More's views of Yearsley's writing plays.

As its title states, chapter five takes up "novel writing and the French Revolution," positioning both writers as overcoming their distaste for novels in order to take advantage of the genre's developing popularity for conveying ideological arguments. Andrews places Yearsley's The Royal Captives (1795) in the tradition of the radical novel and More's Coelebs in Search of a Wife (180809 ) in the anti-Jacobin tradition. Reminding fellow scholars not to overlook seemingly small details, Andrews notes that the $£ 200$ Yearsley was paid for the copyright of her novel was exceptionally high for a first-time novelist and thus suggestive of her publishers' high expectations. Offering another archival gem, Andrews reproduces a letter from Yearsley to an unidentified recipient (possibly one of the Robinson brothers, her publishers) in which Yearsley adopts a different 
posture with respect to patronage, explicitly seeking instruction in novel writing (107). Andrews also explores the literary networks involved in publishing and popularizing More's Village Politics and the Cheap Repository tracts, texts addressed to the laboring classes.

Focusing primarily on Yearsley in chapter six, Andrews discusses examples of radicalism in selections from her last collection of poems, The Rural Lyre (1796), but the chapter may be most valuable for its work establishing Yearsley as a member of publisher Joseph Cottle's radical circle in 1790s Bristol. For Andrews, Cottle presents another variety of patronage, one not grounded in status or wealth: “... Cottle sought to exchange his knowledge and experience [in publishing] for acceptance as a fellow poet by those he helped" (126). A letter recognizing Cottle as a writer identifies Yearsley as no longer simply More's former protégée but a full participant in the circle, able to give and receive feedback. In the Afterword, Andrews traces More's rise in stature in the nineteenth century and Yearsley's relegation to the margins of literary history, concluding by re-asserting her intention not to offer a definitive study but one that inspires further work.

In Ann Yearsley and Hannah More, Patronage and Poetry, Andrews looks both at and beyond what she rightly calls "the well-mined few months of More and Yearsley's literary collaboration" (8), offering a valuable and welcome contribution to Yearsley and More studies as well as to explorations of patronage and literary production during the late eighteenth century. Any shortcomings stem primarily from the book's success in piquing interest in topics that readers may wish had been developed further, especially with respect to literary analysis. In a representative example from chapter 5, exploring literary networks means that Andrews understandably does not focus much on the content of Yearsley's Earl Goodwin (a play that like much of Yearsley's later work has received only limited critical attention). Similarly, the project's focus on literary networks and patronage means that the book continues to see the women through a familiar-if sharper-lens. That said, Andrews extends and deepens our understanding of the women's relationship, while also leaving fertile ground for others to explore. Certainly, much work remains to be done on Yearsley's later writings, and this work will be made easier and richer not only by this monograph but also by Andrews's 2014 three-volume edition of The Collected Works of Ann Yearsley (Pickering and Chatto). 